\title{
Przyszłość językowa Unii Europejskiej: mit wielojęzyczności czy dominacja języka angielskiego?
}

\section{European Union and its Linguistic Future: a Myth of Multilingualism or an English Domination?}

\author{
Marta Borowiak \\ Instytut Językoznawstwa, Uniwersytet im. Adama Mickiewicza \\ al. Niepodległości 4, 61-874 Poznań
}

borowiak.marta@gmail.com

\begin{abstract}
On the threshold of the 21 st century when another 12 states joined the European Union a matter of multilingualism has been recently considered as a crucial factor with regard to European integration process. Having diverse society the UE has started to promote a phrase Unity in Diversity which in turn provides patronage for a number of cultural and education campaigns. Their aim is to prepare the European citizens for cultural integration and to help them to create a sense of European identity. The main assumption of the already taken actions is taking multilingualism as the pillar of the Union and presenting it as an example of equality regardless to citizens' nationality. The herby article reveals however, that the idea of unity in diversity - at least from the linguistic point of view - is practically impossible to accomplish especially in the face of such a strong position of English in the international arena as it has nowadays. What's more, inside Union in its administration structures the idea of equality is not observed. Due to purely practical and organisational reasons just one language is used English. Also English is the foreign language that is taught most often in schools throughout the Europe. A question arises whether the idea of a multilingual Union is not a myth?
\end{abstract}

\section{Stan obecny}

Śledząc artykuły, prasę czy wiadomości na temat Unii Europejskiej, zauważyć można pewną tendencyjność w stawianiu pytań na temat przyszłości Wspólnoty. Polega ona na skupianiu się wokół tych samych problemów i zagadnień. Przykładowo, porusza się kwestie działania $\mathrm{w}$ duchu demokracji oraz skuteczności tego działania przy coraz większej liczbie państw członkowskich. Stawia się pytanie o sens rozszerzania Unii o państwa kandydujące. W toczonych dyskusjach brakuje jednak postrzegania Unii jako zintegrowanego i spójnego „państwa” lub jako partnera strategicznego w gospodarce czy biznesie. Nierozwiązanym punktem pozostaje polityka zagraniczna Unii, bezpieczeństwo państw autonomicznych oraz Wspólnoty jako całości. Również problem przyszłości językowej Unii pozostaje na marginesie oficjalnej dyskusji. Można wysnuć hipotezę, że 
działania w obrębie różnorodności językowej Europy w traktacie lizbońskim ${ }^{1}$ sprowadzają się do kontynuowania podjętych wcześniej rozwiązań w ramach deklaracji bolońskiej. Minusem tego stanu rzeczy jest brak jednoznacznego i definitywnego określenia się Unii w kwestii językowej, plusem natomiast realizacja przyjętych i dobrze rozwijających się programów i inicjatyw kulturowo - edukacyjnych.

W przyszłości Unię ze względu na różnorodność językową i prowadzoną politykę w tym zakresie prawdopodobnie określić będzie można jako Unię wielojęzykową, uznającą równouprawnienie wszystkich państw członkowskich. Prognozują tak przyjęte w pierwszej dekadzie XXI wieku następujące programy edukacyjno - naukowe:

$>$ Europejski Rok Języków (2001) - inicjatywa mająca na celu promowanie nauczania co najmniej dwóch języków europejskich (nie uwzględniając ojczystego), promowanie nieustannego rozwoju na rzecz wielojęzyczności i wielokulturowości oraz jednoczenie obywateli Unii poprzez budowanie w ramach inicjatywy świadomości europejskiej. Kontynuacją projektu jest obchodzony co roku w państwach członkowskich Europejski Dzień Języków. Szczególną uwagę koordynatorzy poświęcają placówkom edukacyjnym, chcąc zainteresować bogactwem i różnorodnością kulturowo - językową dzieci i młodzież w wieku szkolnym, inwestując tym samym w światłych i otwartych obywateli Wspólnoty za kilka lat.

> Europejski Rok Dialogu Kulturowego (2008) - źródłem powstania projektu było znaczne rozszerzenie Wspólnoty w 2004 i 2007 roku. W obliczu prawie $500-$ milionowej społeczności konieczne stało się tworzenie dialogu międzykulturowego, głośne mówienie o poszanowaniu różnorodności kulturowej, zespolenie wielu mniejszych inicjatyw kulturowych na rzecz budowania świadomości europejskiej jako elementu jednoczącego. Warto wspomnieć, że adresatem projektu były nie tylko państwa członkowskie ale również kraje bałkańskie.

$>$ Juvenes Translatores - projekt skierowany jest do siedemnastolatków myślących o zawodzie tłumacza. Swoich sił może spróbować młodzież z wszystkich krajów Wspólnoty, tłumacząc tekst na dowolny spośród 23 oficjalnych języków Unii. Pierwsza edycja konkursu miała miejsce w 2007 roku. Projekt cieszył się dużym zainteresowaniem i odniósł sukces. Organizatorzy postanowili powtórzyć konkurs w roku 2008. Wiele wskazuje na to, że Juvenes Translatores ma szanse stać się cykliczną inicjatywą Unii na rzecz wielojęzyczności.

$>7$ Program Ramowy (7PR) - główny cel programu to stworzenie bazy naukowej i technologicznej, by zgodnie z założeniami deklaracji lizbońskiej, Europa mogła do 2010 roku stać się konkurencyjną (w stosunku do USA), dynamiczną i opartą na wiedzy gospodarką świata. W skład programów szczegółowych 7PR wchodzą: Cooperation (Współpraca), Ideas (Pomysły), People (Ludzie) i Capcities (Możliwości). W szczegółowych założeniach programów People i Capacities znajdziemy zapisy o promowaniu wymiany naukowej w szkolnictwie wyższym poprzez rozwinięte programy stypendialne oraz przybliżenie nauki i technologii społeczeństwom Unii.

$>$ Grupa programów: Comenius, Erasmus, Leonardo da Vinci - ma przede wszystkim charakter edukacyjny i skierowana jest odpowiednio do: Comenius - uczniów szkół podstawowych i gimnazjalnych, Erasmus - studentów, Leonardo da Vinci dorosłych chcących kontynuować rozwój osobisty i zawodowy. Program da Vinci

\footnotetext{
${ }^{1}$ Wspomniane problemy, przynajmniej do pewnego stopnia, reguluje traktat lizboński. Planowo traktat ma obowiązywać od 1 stycznia 2009 roku; wcześniej jednak musi być ratyfikowany przez wszystkich członków Unii. Rangę traktatu podnosi fakt, że służy on jako program działania Wspólnoty na najbliższe kilka, o ile nie kilkanaście lat.
} 
wpisuje się w cykl projektów kształcenia ustawicznego. Wspomniane programy mają kilka cech wspólnych, a mianowicie: dążą do budowania otwartości dla różnorodności kultur $\mathrm{w}$ Europie, wspomagają rozwój osobowościowy i intelektualny uczniów i studentów, przyczyniają się do mobilności zawodowej i prywatnej obywateli oraz (poprzez organizowanie szkoleń i wymiany zawodowej) do konkurencyjności na rynku pracy.

Powyżej w dużym skrócie przedstawiono tylko najważniejsze projekty na rzecz wielojęzyczności i wielokulturowości Unii Europejskiej. Należy wspomnieć, że organizowanych jest jeszcze cały szereg inicjatyw przez proeuropejskie stowarzyszenia czy organizacje pozarządowe, gdzie dofinansowanie z Unii lub jej formalny udział może być niewielki. Znaczna ilość projektów ma zasięg regionalny lub lokalny, co powoduje pewną trudność w dokładnym oszacowaniu liczby projektów na rzecz wielokulturowości i wielojęzyczności Wspólnoty.

Jak się wydaje w obliczu konsekwentnej i spójnej realizacji wspomnianych programów pytanie o przyszłość Unii Europejskiej z punktu widzenia językowego nie powinno budzić obaw. Biorąc pod uwagę ogólne cechy polityki językowej ${ }^{2}$ i sposób jej działania ${ }^{3}$, a więc ustalenie statusu języka, planowanie korpusowe, wdrażanie języka, polityka ta łączy w sobie cechy kultury, edukacji, badań naukowych, handlu i spraw zewnętrznych. Dlatego też kwestia językowa (w każdym razie oficjalnie i deklaratywnie) obecna jest w wielu, na pozór niepowiązanych z nią dziedzinach (ekonomia, gospodarka, polityka, administracja Unii). Pojawiają się pytania, czy obecna sytuacja faktycznie dobrze rokuje? Czy mimo realizacji programów edukacyjnych i podkreślania wagi języków państw członkowskich Unia pozostanie wielojęzyczna? Czy równouprawnienie oficjalnych języków urzędowych nie jest mitem, a dominująca rola języka angielskiego, również $\mathrm{w}$ administracji unijnej, faktem? Czy językowa rzeczywistość we Wspólnocie nie prowadzi do ujednolicenia językowego na rzecz języka angielskiego? Czy to nie wspólny język powinien być dominującym elementem w budowaniu świadomości europejskiej?

Pytania te zmuszają do refleksji nad sensownością kontynuowania obecnej polityki językowej. Gdyby zagłębić się w liczby prezentujące ilość zatrudnianych tłumaczy, przedstawić koszty związane z utrzymaniem służb językowych i zanalizować wyniki raportu 243 Eurobarometru ${ }^{4}$, który mówi o tym, że pierwszym nauczanym językiem obcym jest język angielski, można dojść do wniosku, że kierunek polityki językowej Unii należałoby zmienić. Specjaliści $\mathrm{z}$ wielu dziedzin, pochylający się nad problemem wielojęzyczności, sygnalizują kilka kwestii, które należy wziąć pod uwagę, myśląc o nowej polityce językowej Unii. Są nimi: budowanie spójności Europy przy wykorzystaniu czynnika jednoczącego, jakim jest język, przyznanie dominacji języka angielskiego we Wspólnocie, zgoda na tę dominację lub zaprezentowanie alternatywy.

\section{Język jako element spójności europejskiej}

Doświadczenia pierwszej i drugiej wojny światowej zrodziły konieczność stworzenia takiej organizacji, która $\mathrm{z}$ jednej strony $\mathrm{w}$ możliwie krótkim czasie przyniosłaby społeczeństwom europejskim poprawę warunków życiowych, ekonomiczną stabilizację i dobrobyt; z drugiej zaś, wyrażała sprzeciw wobec niszczących wojen, systemów

\footnotetext{
${ }^{2}$ Główne założenia dotyczące polityki językowej Unii Europejskiej znaleźć można w Traktatach Rzymskich z 1957 roku oraz w Traktacie z Maastricht z 1992 roku.

${ }^{3}$ Phillipson Robert 2005, „Europejczycy właścicielami języka angielskiego?” [w]: Europa właścicieli, red: Zbigniew Galor, Poznań, Wyd KNS A, 2005

${ }^{4}$ EUROBAROMETR $243 \quad$ "Europejczycy i ich języki. Podsumowanie.” 2005,
}

http://ec.europa.eu/public_opinion/archives/ebs/ebs_243_sum_pl.pdf 29.08.2008 
totalitarnych, rasizmu i antysemityzmu . Powstanie najpierw Europejskiej Wspólnoty Węgla i Stali, następnie przekształcenie się jej w dwie równoległe organizacje: Europejską Wspólnotę Gospodarczą i Europejską Wspólnotę Energii Atomowej było zalążkiem obecnej Unii Europejskiej. Dzisiejsza Wspólnota to 27 państw, 23 oficjalne języki urzędowe i około 500 milionów obywateli. Funkcjonowanie tak potężnej organizacji powinno mieć solidne fundamenty, na których można by oprzeć wspólne dla wszystkich cele i działania.

U podstaw wartości, na których straży stoi Unia, leżą: obrona godności osoby ludzkiej (mężczyzny, kobiety lub dziecka), obrona integralności fizycznej i psychicznej, zapobieganie niszczeniu środowiska naturalnego, odrzucenie wszelkiego poniżenia i wszelkiej dyskryminacji ze względu na kolor skóry, religię, język, pochodzenie etniczne, płeć, wiek, niepełnosprawność ${ }^{6}$. Wymienionych powyżej wartości nie można uznać za wyjątkowe czy szczególne, gdyż uznawane one są za uniwersalne wartości moralne, których przestrzega się we wszystkich międzynarodowych organizacjach czy państwach. Integralną częścią każdego państwa jest na przykład naród i jego tożsamość.

W kontekście Unii Europejskiej jako jednego i zgodnego tworu o tożsamości mówić jest raczej trudno. Przez pierwsze lata swojego istnienia Europejska Wspólnota Węgla i Stali, a później Europejska Wspólnota Gospodarcza skupiały się głównie na celach ekonomiczno - gospodarczych. Wyraźne zainteresowanie tożsamością europejską zauważyć można dopiero w latach 90 . XX wieku, kiedy podpisany traktat w Maastricht częściowo regulował kwestie kulturowe i językowe Unii Europejskiej. W obliczu rozszerzającej się Wspólnoty oraz pojawiania się nowych państw kandydujących, problem budowania tożsamości europejskiej, identyfikowania się jako obywatela Unii (a nie koniecznie Francji, Hiszpanii czy Belgii) zaczął być głośno dyskutowany. Obecnie ${ }^{7}$ nadal nie istnieje spójna definicja tożsamości europejskiej ${ }^{8}$, choć coraz częściej podejmowane są próby ustalenia, co należy nazywać tożsamością europejską i jakie powinna mieć ona wyznaczniki. Danuta Huebner definiuje ją jako wyznawanie wspólnych wartości (o których mowa była wcześniej), przezwyciężanie stereotypów obciążających wzajemne stosunki między narodami, poszanowanie dla kulturowej różnorodności, budowanie coraz głębszych więzi między narodami i obywatelami tych narodów oraz czerpanie $\mathrm{z}$ doświadczeń i dorobku innych ${ }^{9}$. Niejednokrotnie elity europejskie próbują nawiązywać do tradycji europejskiej. Należałoby jednak zadać sobie pytanie, czy istnieje coś takiego jak tradycja europejska. Fundamentem tradycji jest historia. Spoglądając na historie państw członkowskich, trudno znaleźć, poza skutkami upadku Cesarstwa Rzymskiego i średniowieczną łaciną, wspólny mianownik. Na przestrzeni wieków, granice Europy oraz jej państw zmieniały się niejednokrotnie i tradycji opartej na historii, bardziej niż w geograficznej Unii Europejskiej, szukać należy w dziejach każdego z państw członkowskich. Elementy czy obiekty, które miałyby odnosić się do tożsamości

\footnotetext{
${ }^{5}$ Propozycje Grupy Intelektualistów ds. Dialogu Międzykulturowego utworzonej z inicjatywy Komisji Europejskiej, „Zbawienne wyzwanie. W jaki sposób wielość języków mogłaby skonsolidować Europę" Bruksela 2008, http://ec.europa.eu/education/policies/lang/doc/maalouf/report_pl.pdf 30.06 .2008

${ }^{6}$ Tamże

${ }^{7}$ Pierwsza dekada XXI wieku

${ }^{8}$ Lewicki Paweł „Co znaczy być Europejczykiem? Poszukiwanie tożsamości europejskiej wśród studentów Berlina”, Wyd. Studia Europejskie 4/2004 http://www.eduvinet.de/eduvinet/pol002.htm 12.09.2008; Konarski Wawrzyniec 2006, „Koniec miodowego miesiąca, czyli głosa do debaty o tożsamości europejskiej”, Euro-limes 1(6) styczeń 2006, Katedra Studiów Europejskich Akademii Ekonomicznej, Kraków 2006 http://www.eurolimes.ae.krakow.pl/files/el1(6)2006/wk_limes1(6).pdf 29.08.2008

${ }^{9}$ Huebner Danuta, „Unia Europejska - otwarta na obywatela, otwarta na świat. Non-paper ws. Przyszłości Unii Europejskiej”, http://european-convention.eu.int/docs/docreg/219.pdf 29.08.2008
} 
europejskiej, są słabo zdefiniowane ${ }^{10}$. Sprawdzić to można, zadając proste pytania: czy powszechnie wiadomo, ile jest gwiazdek na fladze Unii i dlaczego właśnie tyle? Lub dlaczego finał IX symfonii Beethovena jest hymnem Unii? Albo wreszcie, dlaczego Bruksela jest stolicą Wspólnoty? ${ }^{11}$ Flaga czy hymn Unii nie wywołuja takich emocji jak symbole narodowe. Jest tak dlatego, że tożsamość europejska nie jest jeszcze zbudowana ${ }^{12}$. Zaczęto ją budować dopiero po zdiagnozowaniu jej braku. Głównym elementem tworzącym tożsamość, a jednocześnie spajającym narody jest język.

Hofstede $^{13}$ przypisuje językowi nadrzędną rolę w budowaniu i pojmowaniu kultury. Strukturę samej kultury porównuje do warstwowej budowy cebuli, gdzie język, obok symboli, bohaterów, obrzędów czy wartości należy do warstwy zewnętrznej. Używając języka do wyrażenia swojej kultury, człowiek posługuje się pewnym znanym mu programem. Chcąc poznać i zrozumieć inną kulturę, należy odrzucić znany program na rzecz programu nowego (odpowiedniego dla danej kultury). Co więcej, Hofstede traktuje język jako zwierciadło kultury dla danej wspólnoty językowej ${ }^{14}$. To poprzez słowa wyrażana jest rzeczywistość, a więc obraz świata, struktury miejsca, czasu i przestrzeni, światopogląd, emocje, uczucia. Dlatego też, traktując język jako element jednoczący, spajający i odgrywający dominującą rolę w procesie tworzenia tożsamości, stwierdzić należy, że Unia jest zaledwie na progu budowania czegoś, co nazwać można poczuciem tożsamości europejskiej. Trudno zakwestionować fakt, że obywatele Unii nie mają poczucia MY, poczucia wspólnego domu, ojczyzny, poczucia świadomości europejskiej wykraczającej poza granice przede wszystkim państw, ale też partii, religii czy języków ${ }^{15}$. Obecnie, elementy mające pomóc w identyfikacji tożsamości europejskiej, spełniają dodatkowe zadanie w postaci budowania świadomości. Oznacza to, że poza ogólnie przyjętymi w cywilizowanym państwie wartościami moralnymi, to, co scala „Europejczyków”, to flaga, hymn i stolica Unii w Brukseli ${ }^{16}$, choć i tak, jak wspomniano wcześniej, elementy te mają charakter drugorzędny $\mathrm{w}$ konfrontacji $\mathrm{z}$ elementami narodowymi.

Podsumowując, obywatelom zjednoczonej Europy brakuje pewnego poczucia, które odróżniałoby ich od Azjatów, Afrykańczyków czy Północnych Amerykanów, ale jednocześnie łączyło z Czechami, Szwedami i Anglikami ${ }^{17}$. Element, który idealnie nadawałby się do budowania świadomości i tożsamości europejskiej, a więc język, jest poza zasięgiem rozważań. W imię równouprawnienia wszystkich języków urzędowych Unii i czerpania $\mathrm{z}$ różnorodności językowej Wspólnoty, rezygnuje się de facto ze skutecznego budowania wewnętrznej więzi między obywatelami. Rozwiązaniem, proponowanym głównie przez lobby esperantystów, mogłoby być wprowadzenie jednego, wspólnego języka planowego, tzw. europejskiego, przy jednoczesnym podkreślaniu, promowaniu i kontynuacji działań na rzecz wielojęzyczności i wielokulturowości. Inne rozwiązanie proponuje powołana przez komisarza ds. wielojęzyczności - Leonarda Orbana

\footnotetext{
${ }^{10}$ Lewicki Paweł „Co znaczy być Europejczykiem? Poszukiwanie tożsamości europejskiej wśród studentów Berlina”, Wyd. Studia Europejskie 4/2004 http://www.eduvinet.de/eduvinet/pol002.htm 12.09.2008

${ }^{11}$ Tamże

${ }^{12}$ Propozycje Grupy Intelektualistów ... op.cit.

13 Koutny Ilona 2004, „Komunikacja międzykulturowa w Europie: angielski i esperanto jako alternatywne środki komunikacji’[w] Inna (?) Europa red. Barbara Goryńska-Bittner, Poznań Wyd. KNS A, 2004

${ }^{14}$ Tamże

15 Frank Helman G. 1999. „Europa jako wspólnota językowa. Impulsy dla diagnozy terapii” [w] Jaka Europa ma przyszłość? red: Barbara Goryńska-Bittner, Jerzy Stepień, Poznań, Wyd. KNS AR 1999

${ }^{16}$ Do elementów spajających i budujących świadomość europejską dodać można by terytorium. Istnieje jednak duże prawdopodobieństwo, że bardziej terytorium własnego kraju niż terytorium Unii będzie na uprzywilejowanym miejscu.

${ }^{17}$ Frank Helman G. 1999. „Europa ... op.cit.
} 
i Jose Duaro Barossa - Grupa Intelektualistów ds. Dialogu Międzynarodowego. Postulują oni wybranie przybranego języka własnego przez każdego z obywateli Unii.

\subsection{Przybrany język wtasny - ku konsolidacji Europy}

Grupę Intelektualistów ds. Dialogu Międzynarodowego ${ }^{18}$ tworzyli pisarze i osoby zajmujące się zawodowo edukacją i kwestiami językowymi. Wyniki swoich badań oraz komentarze do nich przedstawili na serii trzech posiedzeń, mających miejsce w czerwcu, październiku i grudniu 2007 roku w Brukseli. Koronnym wnioskiem z posiedzeń było twierdzenie mówiące, że Unia powinna być zbudowana na dwóch fundamentach: uniwersalności wspólnych wartości moralnych oraz różnorodności ekspresji kulturowych, w której to różnorodność i wielojęzyczność stanowią istotny element. Rezultatem przeprowadzonych dyskusji były propozycje: 1) stworzenia stosunków dwustronnych między narodami Unii oraz 2) stworzenia przybranego języka własnego ${ }^{19}$.

1) Idea stosunków dwustronnych dotyczy komunikacji językowej między dwoma narodami Unii. Polega ona na tym, że w każdym kraju istnieją grupy kompetentnych osób ds. gospodarki, polityki, kultury itd., a każda z tych grup obsługuje jeden język. Przy 23 językach urzędowych, musiałyby powstać po 23 grupy $\mathrm{w}$ każdym $\mathrm{z}$ państw członkowskich. W zależności od języka partnera rozmów byłyby one prowadzone przez konkretną grupę. Pewna liczba osób w cyklu nauki szkolnej i uniwersyteckiej obejmującej wymianę i wyjazdy stypendialne uczyłaby się konkretnego języka partnera. Kolejnym etapem byłby pobyt w kraju partnera, staż, a następnie zatrudnienie. Do przedsięwzięcia włączyłyby się partnerskie miasta, placówki szkolne, towarzystwa sportowe oraz prywatne przedsiębiorstwa.

2) Przybrany język własny (PJW) ${ }^{20}$ - to język wybrany przez obywatela Unii, będący innym językiem niż jego własny oraz innym od języka komunikacji międzynarodowej. Innymi słowy, miałby to być drugi język ojczysty, nabyty podczas nauki szkolnej i kontynuowany na uczelni wyższej. W procesie nauczania nacisk kładzonoby na literaturę kraju tegoż języka, kulturę, społeczeństwo i historię. Głównym założeniem jest skłonienie Europejczyków do nauki oprócz języka szerszej komunikacji międzynarodowej (prawdopodobnie angielskiego) $^{21}$ takiego języka obcego, jaki spełniałby ich zainteresowania. Co więcej, wybór tego języka miałby być związany z przyszłą karierą zawodową. W konsekwencji wybór ten byłby trwały i świadomy.

Rezultatem wdrożenia przedstawionych propozycji byłaby uprzywilejowana pozycja w stosunkach dwustronnych każdego $\mathrm{z}$ oficjalnych języków Unii oraz duże prawdopodobieństwo, że żaden $\mathrm{z}$ języków nie byłby skazany na zniknięcie lub zredukowany do roli dialektu czy języka lokalnego ${ }^{22}$. Takie podejście mogłoby zapobiec przyszłym kryzysom związanym z poczuciem lekceważenia kultury i języka danej wspólnoty. Pomysłodawcy PJW podkreślają rolę języka jako nośnika pamięci historycznej, dziedzictwa literackiego oraz fundamentu tożsamości kulturowej. Nauka PJW objąć

\footnotetext{
${ }^{18}$ Propozycje Grupy Intelektualistów ... op.cit.

${ }^{19}$ Tamże

${ }^{20}$ Skrót stworzony dla potrzeb pracy.

${ }^{21}$ Prawdopodobnie dla wielu językiem komunikacji międzynarodowej byłby angielski, ale niektórzy może wybraliby hiszpański czy mandaryński.

22 Propozycje Grupy Intelektualistów ... op.cit.
} 
powinna zarówno dzieci i młodzież uczącą się, jak i osoby dorosłe. Dla wszystkich pogłębianie znajomości języka stanowiłoby istotny czynnik rozwoju osobistego. Co więcej, przyczyniałoby się do tworzenia społeczeństwa otwartego na inne kultury nie tylko w obrębie Unii Europejskiej, ale również w stosunku do kultur całego świata. Znajomość PJW znacząco wpłynęłaby na karierę zawodową. Jak zauważają autorzy projektu, język angielski w życiu zawodowym staje się coraz częściej potrzebny, jednak już niedługo może on okazać się niewystarczający. Deklaracja znajomości języka angielskiego wkrótce nie będzie czynnikiem konkurencyjnym na rynku pracy. Umiejętność posługiwania się mniej używanym językiem może stanowić atut potencjalnego pracownika. Korzyści z rozwoju jednostki miałyby ogólnoeuropejskie i ogólnoświatowe przełożenie. Zakładając, że część obywateli wybrałaby języki niekoniecznie europejskie, a na przykład azjatyckie, pojawiłaby się silna i kompetentna grupa ludzi, którzy przyczyniliby się do rozwoju stosunków gospodarczych z krajami spoza Europy. U podłoża sukcesu prowadzonych przez te osoby rozmów leży fakt, że znając dobrze język, kulturę, historię i tradycję danego narodu, można komunikować się w bardziej skuteczny sposób, bacząc na subtelności językowe i konwenanse kulturowe. W rozmowach partnerskich, gdzie językiem komunikacji jest język trzeci, wyczucie niuansów dla każdej ze stron nie zawsze jest możliwe. Do propagowania PJW autorzy proponują wykorzystać nasilające się w Europie zjawisko migracji ludności. Dla imigranta osiedlającego się w danym kraju język tego kraju powinien stać się PJW. Z kolei kraj przyjmujący imigranta musi zrozumieć, jak ważna dla tego człowieka jest możliwość posługiwania się jego językiem i kultywowania tradycji. Zmuszenie imigranta lub osoby wywodzącej się z imigracji do porzucenia swojego języka jest jednoznaczne $\mathrm{z}$ pozbawieniem go korzeni rodzinnych i poczucia łączności ze swoimi przodkami. Dodatkowo może powodować konflikty pokoleniowe wynikające $\mathrm{z}$ niemożności porozumienia się. Społeczeństwa europejskie, w których tendencja imigracji jest silna, niejednokrotnie nastawione są wrogo do nowo osiedlających się osób/grup. Należałoby doprowadzić do zmiany sposobu myślenia. Rodzimi obywatele powinni zdawać sobie sprawę, jakie bogactwo tradycji i kultury przynoszą $\mathrm{z}$ sobą imigranci. Przy dobrej i konsekwentnej polityce asymilacji szeroko rozumiane korzyści (językowe, kulturowe, historyczne, gospodarcze) powinny dotyczyć obu grup.

Przedstawiona propozycja ma wyraźnie charakter teoretyczny. Autorzy przyznają że cały projekt opiera się na osi: założenie-pomysł-skutki realizacji. Głównym celem propozycji jest przekonanie do słuszności, możliwości i sensowności wdrożenia projektu. Uwaga skupiona została na skutkach realizacji pomysłu, przy pewnym założeniu towarzyszących temu kosztów minimalnych, łatwości praktycznej realizacji i nieodległych terminów. Pomysłodawcy przekonani są, że wprowadzenie do programu szkolnego przedmiotu język „nieoczekiwany” nie stanowi większej trudności ani pod względem technicznym, logistycznym, ani kadrowym. Projekt miałaby być wpisany w nurt działań zmierzających do budowy społeczeństwa opartego na wiedzy przy wykorzystaniu dostępnych technologii, na przykład kursów on-line. Mimo zdecydowanych braków w zakresie konkretnego sposobu wdrażania pomysłu we wszystkich krajach członkowskich, powołani eksperci są przekonani co do pełnego wykorzystania wielojęzyczności dla potrzeb osobistych i zawodowych obywateli Unii, przy jednoczesnym zapewnieniu uprzywilejowanej pozycji dla przynajmniej każdego z języków oficjalnych Wspólnoty.

\section{Europejska lingua franca}

W średniowiecznej Europie rolę lingua franca bezsprzecznie pełniła łacina. Uważano ją za język elit. Posługiwano się nią zarówno w uniwersytetach, jak i na dworach królewskich oraz $\mathrm{w}$ zakonach, będących wówczas $\mathrm{w}$ dużej mierze ze względu na panujący system 
feudalny - ważnymi ośrodkami życia politycznego i naukowego. Używając współczesnej terminologii, można powiedzieć, że łacina była językiem komunikacji międzynarodowej średniowiecznej Europy. Nasuwa się pytanie, czy kilka wieków później, w dobie powszechnej globalizacji, można mówić o uniwersalnym języku komunikacji?

Wydaje się, że tak. Nie będzie zaskoczeniem stwierdzenie, że współczesna lingua franca o zasięgu światowym to język angielski. Bez przywoływania badań dotyczących powszechności używania języka angielskiego pewne jest, że jest to język najczęściej używany, uczony i rozumiany. Pod względem liczebności użytkowników konkurować z nim może jedynie język chiński (mandaryński); jednak nawet mieszkańcy Państwa Środka zdają sobie sprawę, że chcąc uczestniczyć w globalnej gospodarce i być znaczącym partnerem na arenie międzynarodowej, muszą znać język angielski. W krajach azjatyckich nauka tego języka wprowadzana jest od najmłodszych lat szkolnych, gdyż w tej chwili państwa takie, jak Chiny, Japonia, Korea Południowa czy wreszcie Indie stają się potęgami technologicznymi, a partnerami biznesowymi tych państw są przede wszystkim Stany Zjednoczone i kraje europejskie. Znajomości języka angielskiego w Ameryce Północnej właściwie nie trzeba tłumaczyć. Mimo że w Kanadzie drugim językiem oficjalnym jest francuski, a w Stanach w siłę rosną języki mniejszości narodowych (głównie hiszpański), język angielski jest nadal językiem dominującym. Nieco inaczej wygląda sytuacja w Ameryce Łacińskiej i Południowej. Tam hiszpański i portugalski są językami wiodącymi. Australia i część państw Afryki to byłe kolonie Wielkiej Brytanii, co w znacznej mierze wyjaśnia stopień znajomości angielskiego na wspomnianych terenach. Pozostaje Europa. $\mathrm{Na}$ tym kontynencie rola i miejsce języka angielskiego różnią się w stosunku do tych, o których była mowa. Powodów jest kilka. Po pierwsze, w Europie ze względów historycznych, popularnością nadal (choć trzeba przyznać że coraz mniejszą) cieszy się język francuski. Ponadto, jest to język powszechnie używany w 4 krajach: Francji, Luksemburgu, Belgii i Szwajcariii ${ }^{23}$. Silną pozycję ma język niemiecki. Używa się go w 5 krajach $^{24}$ : Niemczech, Austrii, Szwajcarii, Luksemburgu i Belgii. Dodatkowo, Niemcy nieustannie od kilku dekad są potęgą ekonomiczną Europy. Kolejnym czynnikiem wpływającym na jeszcze nie do końca dominujący w Europie język angielski jest nacjonalistyczne podejście obywateli danego kraju do swojego języka, który stanowi o przynależności i tożsamości narodowej/etnicznej, czego świadomi są obywatele Europy. Nie zmienia to jednak faktu, że prawdopodobnie w najbliższych latach język angielski zdobędzie pozycję uprzywilejowaną. Przesłankami ku temu mogą być choćby wyniki 243 Raportu Eurobarometru ${ }^{25}$, mówiące o tym, że najczęściej używanym i nauczanym językiem obcym w Europie jest język angielski. W przytoczonych badaniach analizowano sytuację głównie w krajach Unii Europejskiej. Czy oznaczałoby to, że Wspólnota teoretycznie jest wielojęzyczna, ale praktycznie anglojęzyczna? Czyż w rozbudowanej administracji unijnej nie używa się w zasadzie tylko jednego języka - angielskiego? Biorąc pod uwagę fakt, że w instytucjach w Brukseli słyszy się głównie angielski ${ }^{26}$ - odpowiedź jest jasna. Przypomnieć jednak należy, że Unia kładzie nacisk na promowanie wielojęzyczności. Zachowanie różnorodności językowej i kulturowej przyjmuje za swój priorytet. Można więc przyjąć, że w Unii Europejskiej nie jest jeszcze obecna lingua franca, jednak Wspólnota staje się coraz bardziej ,angielska”.

\footnotetext{
${ }^{23}$ Koutny Ilona 2004, „Komunikacja ... op.cit.

${ }^{24}$ Tamże

${ }^{25}$ EUROBAROMETR 243 ... op.cit.

${ }^{26}$ Frank Helman G. 1999. „Europa ... op.cit.
} 


\subsection{Angielska Europa}

W pierwszych latach działalności Unii, kiedy językami oficjalnymi były francuski, niemiecki, włoski i niderlandzki, liczba możliwych kombinacji językowych pod względem thumaczenia wynosiła $12^{27}$. Jednak $\mathrm{z}$ dodaniem kolejnych języków oficjalnych, liczba możliwych kombinacji w tłumaczeniach rosła nieproporcjonalnie. W latach 70., wraz z przystapieniem do Unii Anglii i Danii, liczba ta wynosiła 30. W 1997 roku, kiedy Wspólnota składała się z 11 członków, kombinacji językowych było już 110. Obecnie Unia Europejska to 23 języki urzędowe i 506 kombinacji językowych ${ }^{28}$. Oczywistym ułatwieniem byłoby posługiwanie się $\mathrm{w}$ Unii lub przynajmniej $\mathrm{w}$ instytucjach administracyjnych jednym językiem. Język angielski ze względu na swoją powszechność wydaje się naturalnym wyborem. Pod uwagę należałoby brać jeszcze język francuski i niemiecki. Język francuski ze względu na swoją wpływową pozycję w XVII, XVIII i jeszcze nawet w XIX wieku cały czas ma skłonności do objęcia roli języka dyplomacji i salonów politycznych. Niemiecki z kolei jest językiem używanym przez największą pod względem liczebności społeczność Unii. Dodatkowo, Niemcy to potęga ekonomiczna i gospodarcza Europy oraz znaczący finansowo członek Wspólnoty. Niemniej jednak, wybranie jednego języka, zwłaszcza języka ojczystego jednego z krajów członkowskich, kłóci się z zasadami polityki językowej Unii. Inne kraje członkowskie o słabszej pozycji międzynarodowej pod względem na przykład ekonomicznym, gospodarczym czy chociażby terytorialnym czułyby się zagrożone ${ }^{29}$. Społeczności językowe świadome roli języka w kształtowaniu tożsamości narodowej czy społecznej, mogłyby odebrać drugorzędną rolę swojego języka jako zniewagę. Unii z kolei, zarzuconoby faworyzowanie i uprzywilejowanie jednego języka, co wiązałoby się $z$ imperializmem językowokulturowym. Biorąc pod uwagę fakt, że najprawdopodobniej byłby to język angielski (ewentualnie francuski czy niemiecki) niezadowolenie czy wręcz niezgoda na wybór języka ekonomicznie czy politycznie dominującego byłaby nieunikniona.

Z drugiej jednak strony, paradoksem jest twierdzić, że w obecnej Unii Europejskiej język angielski nie odgrywa uprzywilejowanej roli. Znaczny wpływ na taką sytuację ma rola języka angielskiego na świecie i potęga USA, o czym była już mowa wcześniej. Dlatego można by zaryzykować tezę mówiącą o tym, że Europa jest faktycznie anglojęzyczna.

Przyjrzyjmy się politycznym powiązaniom Unii $\mathrm{z}$ innymi międzynarodowymi organizacjami $^{30}$. Pakt Północnoatlantycki (NATO) utworzono w 1949 roku. Sojusz polityczno - wojskowy podpisały USA, Kanada i kraje Europy Zachodniej ${ }^{31}$. Obecnie NATO to 26 krajów. Znaczna część z nich to również kraje będące członkami UE. Językiem komunikacji i obrad od samego początku był język angielski. Wybór języka wydawał się dość oczywisty ze względu na pozycję USA w latach 50. Ogniwem NATO silnie współpracującym z Unią jest Unia Zachodnioeuropejska (UZE) z siedzibą w Brukseli. Również tutaj językiem dowodzenia jest angielski. Innymi organizacjami o

\footnotetext{
27 Gramkow Karsten 1997, "An Administrative Lingua Franca within the EU" , Aalborg University,Denmark http://earth.subetha.dk/ eek/museum/auc/marvin/www/library/uni/projects/adlfineu.htm 23.05.2008

28 Strona Parlamentu Europejskiego, „Ilu języków używa się w Parlamencie Europejskim?” http://www.europarl.europa.eu/parliament/public/staticDisplay.do?id=155\&pageRank=2\&language=PL 12.09.2008

${ }^{29}$ Gramkow Karsten 1997, "An Administrative ... op.cit.

${ }^{30} \mathrm{Na}$ podstawie analizy zamieszczonej w: Frank Helman G. 1999. „Europa jako wspólnota językowa. Impulsy dla diagnozy terapii" [w] Jaka Europa mai przyszłość? red: Barbara Goryńska-Bittner, Jerzy Stepień, Poznań, Wyd. KNS AR 1999

31 http://www.nato.int/ 13.09.2008, Kraje Europy Zachodniej: Belgia, Dania, Francja, Holandia, Islandia, Luksemburg, Norwegia, Portugalia, Wielka Brytania, Włochy
} 
zasięgu globalnym, z którymi Unia jest silnie powiązana $\mathrm{są}^{32}$ : Międzynarodowa Organizacja Handlu (WTO), Organizacja Narodów Zjednoczonych (ONZ), Rada Europy (CoE), Grupa Ośmiu (G8), Europejska Strefa Ekonomiczna (EEA), Południowoazjatyckie Stowarzyszenie Współpracy Regionalnej (SAARC) oraz wiele innych. Powyższe organizacje przytoczono $\mathrm{W}$ celu pokazania liczebności państw, $\mathrm{z}$ którymi Unia współpracuje na różnych szczeblach swojej działalności. Narzędziem współpracy jest ponownie język angielski. Ponieważ decyzje przywołanych podmiotów mają zasięg globalny, absurdem byłoby poruszanie kwestii języka komunikacji na spotkaniach, zgromadzeniach czy szczytach. Co więcej, Unia uczestnicząca w anglojęzycznych obradach traktowana jest jako jednostka reprezentująca pewną większość. W ten sposób rodzi się pogląd o komunikacyjnie angielskojęzycznej Europie. Z drugiej strony trudno wyobrazić sobie, by było inaczej. Biorąc udział w spotkaniach o charakterze międzynarodowym, gdzie język angielski jako język komunikacji i biznesu ma ustaloną pozycję, Unia jako partner - często strategiczny - zachowywałaby się inaczej. Podsumowując, Wspólnota na ekonomiczno - politycznej arenie międzynarodowej, jest podmiotem anglojęzycznym.

Kolejnym faktem przemawiającym za pozorną równością czy wielojęzycznością Unii jest sposób i kolejność tłumaczeń. W Parlamencie Europejskim obrady tłumaczone są na wszystkie 23 języki urzędowe. Jak wspomniano wyżej, daje to 506 kombinacji językowych. Nierzadko zdarza się, że tłumacz z danej pary językowej, np. fiński-czeski, jest niedostępny w określonym czasie. Stosuje się wówczas tłumaczenie „via język"33, czyli tłumaczy się z języka pośredniego. Praktycznie wygląda to tak, że tłumacz słucha najpierw wersji thumaczonej $\mathrm{z}$ fińskiego na angielski, a następnie thumaczy on $\mathrm{z}$ angielskiego na czeski. W tej sytuacji ryzyko przekazania niedokładnej informacji jest tym większe, że po pierwsze, tłumaczenie jest symultaniczne, co już wiąże się z ok. $10 \%$ stratą informacji $^{34}$, po drugie, thumaczy się już przefiltrowany produkt, co z kolei prowadzi do kolejnych strat informacji; i po trzecie wreszcie, końcowy komunikat podaje się $\mathrm{z}$ kilkusekundowym opóźnieniem. Efektem tego opóźnienia może być niewłaściwa reakcja (spóźniony śmiech, zaskoczenie, sprzeciw) parlamentarzysty lub innej osoby oczekującej na informacje. Pozostając w obrębie tłumaczeń, należy zauważyć, że najczęściej stosowanym językiem przy tłumaczeniach pośrednich jest angielski, gdyż liczba osób, w tym thumaczy znających ten język, stale rośnie ${ }^{35}$. Co więcej, przez „popularyzację” thumaczeń wykorzystujących angielski wzbogaca się jego terminologia, choćby z zakresu prawa, gdyż większość dekretów czy rozporządzeń tłumaczonych na język angielski. W rezultacie, powstają nowe departamenty i komisje, znane wewnątrz Unii, rozumiane dla partnerów zewnętrznych ale niemających swoich odpowiedników w podobnych strukturach krajowych czy lokalnych w danym państwie członkowskim. Podobnie sytuacja wygląda w kwestii wzbogacenia języka angielskiego o terminologię ekonomiczną i gospodarczą. Przy pracy w zasadzie nad jakimkolwiek projektem czy z zakresu rozwoju regionalnego czy wdrażania nowych technologii informacyjnych, zespół specjalistów pracujących nad nim musi mówić jednym językiem nie tylko ze względu na kwestie

\footnotetext{
${ }^{32}$ Przytoczone adresy internetowe odwołują się do stron traktujących o współpracy Unii z poszczególnymi organizacjami (12.09.2008) European Commission, External Relations: http://ec.europa.eu/external_relations/eea/index_en.htm 12.09.2008; European Economic Area http://ec.europa.eu/external_relations/g7_g8/intro/index.htm 12.09.2008 G7 - G8; http://ec.europa.eu/external_relations/coe/index.htm $12.09 .2008 \quad$ Council of Europe; http://ec.europa.eu/external_relations/saarc/intro/index.htm 12.09.2008 South Asian Association for Regional Cooperation; $\quad \mathrm{http}: / /$ ec.europa.eu/external_relations/un/index.htm $12.09 .2008 \quad$ United Nations; http://ec.europa.eu/trade/issues/newround/index_en.htm, 12.09.2008 Word Trade Organization, „The EU and the WTO”

${ }_{33}$ Hans Malv2004, „Nieporozumienia językowe w obrębie Unii Europejskiej” http://www.2-2.se/pl/3.html 12.09.2008

${ }^{34}$ Tamże

${ }^{35}$ Wniosek wysnuty na podstawie porównania wyników Eurobarometru: Raport 15 z 2001 roku i Raport 243 z 2005 roku
} 
merytoryczne, ale przede wszystkim z punktu widzenia praktycznej komunikacji. Tym językiem jest oczywiście język angielski (rzadziej francuski lub niemiecki). Prostym wytłumaczeniem stosowania angielskiego jest fakt, że literatura fachowa w znacznej mierze publikowana jest po angielsku. Naukowcy i eksperci mający do niej dostęp, sami przyczyniają się do powstania nowych badań, których rezultaty publikują w czasopismach o zasięgu międzynarodowym. W ten sposób krąg się zamyka.

O dominującej pozycji języka angielskiego świadczą cytowane już wcześniej wyniki Eurobarometru $^{36}$. Badanie przeprowadzono w dniach od 5 listopada do 7 grudnia 2005 roku na grupie 28694 obywateli w wieku co najmniej 15 lat, z 25 państw UE oraz kandydujących wówczas Bułgarii, Rumunii, Chorwacji i Turcji. Wyniki pokazały, że 56\% respondentów jest $\mathrm{w}$ stanie prowadzić rozmowy w co najmniej jednym języku obcym, $28 \%$ w co najmniej 2 językach obcych, a $11 \%$ w co najmniej trzech. Jeżeli chodzi o język najczęściej używany, to pierwsze miejsce zajmuje zdecydowanie angielski. Posługuje się nim $51 \%$ respondentów, z czego $13 \%$ to natywni użytkownicy tego języka. Na drugim miejscu znajduje się język niemiecki; używa go $32 \%$ obywateli, z czego ponad połowa, bo $18 \%$ to użytkownicy rodzimi. Różnica miedzy liczbą użytkowników języka angielskiego i niemieckiego jest znaczna. Pogłębia ją dodatkowo fakt, że rodzimi użytkownicy języka niemieckiego stanowią największą liczebnie grupę. Dominacja języka angielskiego w Unii nad pozostałymi będzie się cały czas zwiększać. Dowodem na to mogą być liczby świadczące o wyborze nauki języka obcego przez dzieci. W badaniu respondentom zadano następujące pytanie: Pana zdaniem jakich dwóch języków obcych poza Pana(i) językiem ojczystym powinny się uczyć dzieci? 77\% badanych odpowiedziało, że powinien to być język angielski. Średnia odpowiedzi byłaby znacznie większa gdyby kraje, w których język angielski jest powszechnie używany, a więc Anglia i Irlandia, udzieliły innych odpowiedzi (odpowiednio 5\% i 3\%).

$\mathrm{Na}$ tak uprzywilejowaną pozycję angielskiego wpływ ma przede wszystkim postępujący proces globalizacji i postęp technologiczny. Z historycznego punktu widzenia Wielka Brytania to kolonialna potęga w XIX wieku i jeszcze częściowo w pierwszej połowie XX. Stany Zjednoczone $\mathrm{z}$ kolei to supermocarstwo po wydarzeniach drugiej wojny światowej ${ }^{37}$. USA, przyczyniając się do procesu komputeryzacji, rozwoju telekomunikacji, technologii informacyjnych i środków masowego przekazu, promowały język angielski jako język techniki i mediów. W konsekwencji angielski zaczął przenikać do kolejnych dziedzin życia. Obecnie język angielski jest podstawowym narzędziem w potężnej machinie popkultury. Znakomita większość filmów powstaje w USA czyniąc kino europejskie niemal alternatywnym a gwiazdy $\mathrm{z}$ dużego amerykańskiego ekranu, wydają się tak znajome jak te, we własnym kraju. Początkujący artyści muzyki pop mają większe szanse na odniesienie sukcesu, tworząc i wykonując utwory w języku angielskim niż rodzimym. Dodatkowo, ze względu na choćby powierzchowną znajomość angielskiego, do języków rodzimych wkradają się zmodyfikowane słowa angielskie ${ }^{38}$. Część z nich zostaje przyjęta. $Z$ czasem słowa te postrzegane są jako stały, niezastapiony element słownika. Przykładem moga być nazwy całej gamy urządzeń elektronicznych oraz części komputerowych czy teleinformatycznych. Można powiedzieć, że powstał międzynarodowy żargon bazujący na języku angielskim. Takie żargony zrodziły się niemal we wszystkich dziedzinach poruszanych na szczeblu międzynarodowym. Pojawiło się specyficzne słownictwo i

\footnotetext{
${ }^{36}$ EUROBAROMETR 243 "Europejczycy ... op.cit.

${ }^{37}$ Gramkow Karsten 1997, "An Administrative ... op.cit.

${ }^{38}$ Korcz Paweł Matulewski Marek, 2006. „Wpływ globalizacji na powstanie polsko-angielskiego pidżynu zawodowego” [w] : Język, komunikacja, informacja. red. P. Nowak, P. Nowakowski, Poznań, Wyd. Sorus 2006; Wiertlewski Stefan 2007. „Czy polski język ulega pidżynizacji?” [w]: Język, komunikacja, informacja. red. P. Nowak, P. Nowakowski, Poznań, Wyd. Sorus 2007
} 
struktury językowe odpowiednie w danym sektorze ${ }^{39}$. Trudno wyobrazić sobie, by fizycy czy lekarze posługiwali się angielskim typu $\mathrm{RP}^{40}$. Dlatego też angielski międzynarodowy ma uproszczone struktury gramatyczne $\mathrm{i}$ tzw. core vocabulary ${ }^{41}$, czyli powszechnie znany $\mathrm{i}$ używany zestaw słownictwa.

Należy się zastanowić, jakie konsekwencje ma globalne promowanie jednego z języków Unii. Otóż powszechna niemalże nauka języka angielskiego przez ludzi w każdym wieku wywarła znaczący wpływ na rozwój i gospodarkę Wielkiej Brytanii. Według raportu szwajcarskiego profesora François Grin $^{42}$ dominująca pozycja języka angielskiego daje przychód angielskiej gospodarce rzędu 17 - 18 miliardów euro rocznie, co stanowi $1 \%$ dochodu narodowego brutto Wielkiej Brytanii. Innymi słowy, około 394 milionów obywateli Unii, niebędących Brytyjczykami, dotuje brytyjską gospodarkę. Ta pokaźna suma jest wynikiem sprzedaży głównie książek i materiałów dydaktycznych do nauki języka angielskiego. Do tego dochodzą kursy językowe w Zjednoczonym Królestwie powiązane $\mathrm{z}$ turystyką, na której korzysta branża hotelowa $\mathrm{i}$ gastronomiczna. Kolejnym elementem miliardowej sumy są rozpowszechnione odpłatne kursy i egzaminy prowadzone przez British Council. Prestiż organizacji oraz jakość nauczania i aprobata materiałów dydaktycznych przez BC spowodowały, że egzaminy językowe wyższego stopnia $\mathrm{z}$ logo i pieczątką tej organizacji uznawane są przez znakomitą większość instytucji i placówek edukacyjnych w Europie, a także na świecie. Nauka i promowanie nauczania języka angielskiego doskonale wpisują się we wspierany i propagowany przez Unię nurt kształcenia ustawicznego, związanego $\mathrm{z}$ podnoszeniem kompetencji zawodowych i osobistych. Organizowany jest cały szereg szkoleń z języka angielskiego dla osób pracujących zawodowo oraz dla nauczycieli angielskiego, chcących podnosić swoje kwalifikacje w tej materii. Szkolenia, czasem refundowane w całości lub częściowo przez zakłady pracy, czasem dofinansowane przez Unię, są kolejnym źródłem dochodu w sektorze edukacyjnym Wielkiej Brytanii, która jak na ironię ma jeden $\mathrm{z}$ najniższych wskaźników znajomości języka obcego wśród krajów Unii Europejskiej.

Przedstawione powyżej czynniki można uznać za kluczowe w dominującej pozycji języka angielskiego w Europie. Nieustannie napędzaną machinę promocji angielskiego i powszechną jego znajomość trudno zatrzymać. Machinę tę można by jedynie spowolnić, a naukę ograniczyć, jednak nasuwa się pytanie o sensowność takich działań, gdyż Unia Europejska nie jest odizolowaną wyspą, a częścią globalnej, często anglojęzycznej wioski.

\section{Podsumowanie}

Unia Europejska dokłada wszelkich starań, by szczytne założenia miały swoje odzwierciedlenie w rzeczywistości. Efektem tego jest cały szereg inicjatyw i programów kulturowo-edukacyjnych. Ambitne plany wdrażane w ramach traktatu lizbońskiego psuje jednak ,popularność” języka angielskiego. W tej sytuacji prace nad wielojęzycznością i promocją różnorodności językowej w Europie nijak się mają do silnej i stale umacniającej się pozycji tego języka. Hasła propagujące równouprawnienie językowe wydają się pustymi frazesami, a wzniosły cel stworzenia Europy, w której języki mniejszości narodowych mają równy status z językami silnymi ekonomiczne, utopijny. Przy takim stanie rzeczy trudno jest mówić o budowaniu świadomości europejskiej, której solidnym fundamentem byłby język, gdyż takiego fundamentu brak. Można by pokusić się o twierdzenie, że to wielojęzyczność ma być podstawą owej świadomości. Jednak wielojęzyczność to obecna sytuacja, a świadomości europejskiej obywateli Unii nie widać.

\footnotetext{
${ }^{39}$ Koutny Ilona 2004, „Komunikacja ... op.cit.

${ }^{40} \mathrm{RP}$ - Received Pronunciation

${ }^{41}$ Gramkow Karsten 1997, "An Administrative ... op.cit.

${ }^{42}$ François Grin " Applying economics to language: what are the relevant questions to ask?" http://en.nitobe.info/ar/kampanjoj/grin-letero.php 23.05.08
} 
Marta Borowiak: Przyszłość językowa Unii europejskiej:

mit wielojęzyczności czy dominacja języka angielskiego

Aby rozwiązać ten problem, należy: oficjalnie uznać język angielski jako dominujący i urzędowy Unii przy poszanowaniu pozostałych języków oraz promowaniu ich $\mathrm{w}$ świadomości społeczeństwa europejskiego lub przyjąć inny język nieeuropejski, którego promocja nie nobilitowałaby kraju, państwa czy społeczności nim się posługujących. 


\section{Bibliografia}

EUROBAROMETR 243 “Europejczycy i ich języki. Podsumowanie.” 2005, http://ec.europa.eu/public_opinion/archives/ebs/ebs_243_sum_pl.pdf 29.08.2008

European Commission, External Relations:

http://ec.europa.eu/external relations/eea/index en.htm 12.09.2008; European Economic Area http://ec.europa.eu/external relations/g7 g8/intro/index.htm 12.09.2008 G7 - G8; http://ec.europa.eu/external_relations/coe/index.htm 12.09.2008 Council of Europe; http://ec.europa.eu/external_relations/saarc/intro/index.htm 12.09.2008 South Asian Association for Regional Cooperation; http://ec.europa.eu/external relations/un/index.htm 12.09.2008 United Nations; http://ec.europa.eu/trade/issues/newround/index en.htm, 12.09.2008 Word Trade Organization, „The EU and the WTO"

Frank Helman G. 1999. „Europa jako wspólnota językowa. Impulsy dla diagnozy terapii” [w] Jaka Europa ma przyszłość? red: Barbara Goryńska-Bittner, Jerzy Stepień, Poznań, Wyd. KNS AR 1999, Gramkow Karsten 1997,

"An Administrative Lingua Franca within the EU" , Aalborg University,Denmark http://earth.subetha.dk/ eek/museum/auc/marvin/www/library/uni/projects/adlfineu.htm 23.05.2008

Hans Malv2004, „, Nieporozumienia językowe w obrębie Unii Europejskiej” http://www.2-2.se/pl/3.html 12.09.2008

Huebner Danuta, „Unia Europejska - otwarta na obywatela, otwarta na świat. Non-paper ws. Przyszłości Unii Europejskiej”, http://european-convention.eu.int/docs/docreg/219.pdf 29.08.2008

Konarski Wawrzyniec 2006, „Koniec miodowego miesiąca, czyli glosa do debaty o tożsamości europejskiej”, Eurolimes 1(6) styczeń 2006, Katedra Studiów Europejskich Akademii Ekonomicznej, Kraków 2006 http://www.eurolimes.ae.krakow.pl/files/el1(6)2006/wk limes1(6).pdf 29.08.2008

Koutny Ilona 2004, „Komunikacja międzykulturowa w Europie: angielski i esperanto jako alternatywne środki komunikacji”[w] Inna (?) Europa red. Barbara Goryńska-Bittner, Poznań Wyd.KNS AR 2004,

Lewicki Paweł „Co znaczy być Europejczykiem? Poszukiwanie tożsamości europejskiej wśród studentów Berlina”, Wyd. Studia Europejskie 4/2004 http://www.eduvinet.de/eduvinet/pol002.htm 12.09.2008

Matalewski Marek, Korcz Paweł 2006. „Wpływ globalizacji na powstanie polsko-angielskiego pidżynu zawodowego” [w] : Język, komunikacja, informacja. red. P. Nowak, P. Nowakowski, Poznań, Wyd. Sorus 2006,

François Grin “ Applying economics to language: what are the relevant questions to ask?" http://en.nitobe.info/ar/kampanjoj/grin-letero.php 23.05.08

Phillipson Robert 2005, „Europejczycy właścicielami języka angielskiego?” [w]: Europa właścicieli, , red: Zbigniew Galor, Poznań, Wyd KNS AR 2005,

Propozycje Grupy Intelektualistów ds. Dialogu Międzykulturowego utworzonej z inicjatywy Komisji Europejskiej, „Zbawienne wyzwanie. W jaki sposób wielość języków mogłaby skonsolidować Europę” Bruksela 2008, http://ec.europa.eu/education/policies/lang/doc/maalouf/report_pl.pdf 30.06.2008

Strona Parlamentu Europejskiego, „Ilu języków używa się w Parlamencie Europejskim?” http://www.europarl.europa.eu/parliament/public/staticDisplay.do?id=155\&pageRank=2\&language=PL 12.09.2008

Wiertlewski Stefan 2007. „Czy polski język ulega pidżynizacji?” [w]: Język, komunikacja, informacja. red. P. Nowak, P. Nowakowski, Poznań, Wyd. Sorus 2007 